\title{
A Simple, Quantitative Peroxidase Assay Demonstrating Enzyme Inhibition with L-cysteine
}

\author{
Michael Mitsch ${ }^{1}$ and Bryan White ${ }^{2}$
}

\author{
${ }^{1}$ Okanagan College, Department of Biology, 7000 College Way, Vernon BC V1B 2N5 CAN \\ ${ }^{2}$ Okanagan College, Department of Biology, $255210^{\text {th }}$ Ave NE, Salmon Arm BC V1E 2S4 CAN \\ (mmitsch@okanagan.bc.ca; bgwhite@okanagan.bc.ca)
}

\begin{abstract}
We present a simple enzyme assay using the robust horseradish peroxidase and the indicator guaiacol which, when oxidized to form tetraguaiacol, can be detected and quantified using a visible spectrophotometer at $470 \mathrm{~nm}$. This assay uses buffers $\left(\mathrm{NaPO}_{4}\right)$, substrates $\left(\mathrm{H}_{2} \mathrm{O}_{2}\right)$ and equipment already widely used and available in most first-year laboratories and is a cost-effective addition to current experiments. In addition to determining and comparing specific activity under a variety of traditional variables $(\mathrm{pH}$, temperature) participants will use L-cysteine, reported in the literature to be a non-competitive inhibitor of peroxidase. Lcysteine demonstrates a unique inhibition pattern in our assay losing its inhibitory characteristics in a concentration and time dependent manner. This gives the instructor a range of options to demonstrate enzyme inhibition as well as an opportunity for investigations and self-directed experimentation by the students with a more challenging result to consider and analyze.
\end{abstract}

Keywords: biochemistry, peroxidase, enzyme assay, guaiacol, inhibition, L-cysteine, inquiry-based learning

\section{Introduction}

We identified a need for a simple, economical quantitative assay to assist students in understanding enzyme activity. Most quantifiable enzyme assays utilize cofactor reduction and observation using UV spectrophotometers which is beyond the budget of most first-year biology classes. In the past oxidizable indicators such as guaiacol (Maehly and Chance, 1954, Koduri and Tien, 1995, Doerge et al. 1997) have been used in conjunction with the robust horse radish peroxidase and we sought to revive this old technique. We also wanted to modify it to include an experiment beyond traditional enzyme inhibition with abiotic factors such as temperature or $\mathrm{pH}$ which simply reduce or eliminate enzyme function. Instead, we wanted to explore enzyme inhibition from a cellular or metabolic perspective by including relevant enzyme inhibitors that were part of a negative feedback loop or substrate analogs which would reduce, but not eliminate enzyme function.

\section{Inhibitors of Peroxidase}

A brief literature search (Peroxidase Inhibitors, Sigma Bulletin) identified several potential inhibitors but some had no obvious cellular or metabolic significance (2-imidazolidinethione purum,sodium azide) and some would be problematic in an undergraduate laboratory (sodium cyanide). A potential substrate analog sodium orthovanadate was tested but showed no inhibition in our assay and at high concentrations produced a pigment which made spectrophotometric readings unreliable. We determined that L-cysteine may be a suitable candidate as it had been reported to inhibit peroxidase activity from avocado by $93 \%$ and reduced the $V_{\max }$ indicative of a non-competitive inhibitor (RojasReyes et al. 2014). In our assay L-cysteine demonstrates a unique inhibition pattern (Fig.2) losing its inhibitory characteristics in a concentration and time dependent manner. Our initial hypothesis was that the L-cysteine was being oxidized to the dimer L-cystine and as its concentration was reduced it lost its inhibitive properties. This possibility is confusing as Lcystine is also listed as an inhibitor of peroxidases (Peroxidase Inhibitors, Sigma Bulletin). It is also possible that the oxidation of L-cysteine to L-cystine competes with the oxidation of guaiacol to tetraguaiacol thus reducing its formation resulting in the lack of

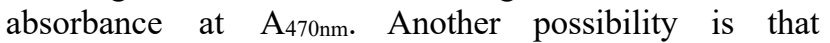
peroxidase is known to mimic catalase in producing $\mathrm{O}_{2}$ (Baker et al. 2000, Hiner et al. 2001) and we theorize that this $\mathrm{O}_{2}$ could interact with L-cysteine converting it to cysteine sulfinic acid thus losing its inhibitory characteristics during the assay. Recently peroxidase has been used to modify, map and quantify 
cysteine residues in proteins (Toledo et al. 2011) so its interaction with L-cysteine is not surprising. Despite no definitive cause to the inhibition, the assay we have adopted (Purdue University Instrument Van Project) and modified is an easy, fast (10 minutes per assay), reliable, and cheap experiment with most equipment (visible spectrophotometers, test tubes, micropipetters) and reagents $\left(\mathrm{H}_{2} \mathrm{O}_{2}, \mathrm{NaPO}_{4}\right)$ already available in most undergraduate labs with only the indicator guaiacol being an addition to inventory. The experiment as we have outlined it can be completed in a three-hour laboratory period and expands on traditional qualitative enzyme assays done at the first year/introductory level. The students who have conducted this experiment have found the explanation for the inhibition pattern to be much more challenging to formulate, explain and present. This leads to an enhanced appreciation for enzymes, assays, and generating theories to explain data in either question format or a complete laboratory report.

\section{Future Possibilities}

This assay lends itself to further development (kinetics and zymograms) and may be expanded to fulfill the needs of more sophisticated upper level biochemistry courses. 


\section{Student Outline}

\section{Objectives}

- Use visible spectrophotometers and excel spreadsheets to calculate and compare enzyme activity

- Understand abiotic effects on enzyme activity

- Theorize how L-cysteine may affect peroxidase activity

\section{Introduction}

Living cells carry out a multitude of chemical reactions necessary for the continuance of life. Many of these reactions normally occur slowly or not at all at temperatures typical for cells. Enzymes serve as biological catalysts that decrease the amount of energy required to initiate a reaction, thereby enabling the reaction to proceed readily at moderate temperatures. The energy required is called the activation energy, so an enzyme lowers the activation energy for a reaction. The specific molecule or molecules that are acted upon by an enzyme are called substrates. In an enzyme-catalyzed reaction, the enzyme combines physically with the substrate(s) to form an enzyme-substrate complex; the act of combining may promote the reaction by distorting particular chemical bonds in the substrate making them easier to break, or it may bring specific areas of different substrate molecules close to each other so that a bond between them can be formed more readily. The products formed are then released from the surface of the enzyme. This process may be summarized by the following equation:

$$
\text { Enzyme }+ \text { Substrate }(s) \stackrel{\text { yields }}{\longrightarrow}(\text { Enzyme Substrate Complex }) \stackrel{\text { yields }}{\longrightarrow} \text { Product }(s)+\text { Enzyme }
$$

Note that the enzyme molecule is released unchanged and can react with additional substrate molecules. It is important to recognize, however, that enzymes are not possessed of some mystical power to promote chemical reactions that otherwise would not occur. Enzymes do not change the thermodynamic equilibrium of a reaction; they merely increase the rate of reaction and thus speed the approach to chemical equilibrium. Consequently, they speed the reverse as well as the forward reaction.

Structurally enzymes consist of a long chain of amino acids and the amino acids interact with each other to form a complex coiled or folded structure that has a specific 3-dimensional shape. Each different enzyme has a unique shape and can catalyze only one particular reaction or class of reaction. Anything that disrupts the shape of an enzyme can alter its catalytic effectiveness. Usually an enzyme operates best at a particular temperature and $\mathrm{pH}$. Higher temperatures generally speed up chemical reactions but for enzyme-catalyzed reactions, when the temperature becomes too great, the hydrogen bonds, which help to stabilize the enzyme's shape, are broken. When this occurs, the enzyme is said to be denatured. Changes in $\mathrm{pH}$ can also denature an enzyme and reduce its effectiveness. In addition to environmental factors such as $\mathrm{pH}$ or temperature compounds with similar structures to the substrate may compete for binding at the active site even though these compounds cannot be converted to a product by the enzyme resulting in competitive inhibition of the enzyme. These compounds are referred to as substrate analogs. Alternatively, some compounds may bind the enzyme away from the active site but their binding changes the three-dimensional shape of the active site of the enzyme (allosteric regulation) reducing or eliminating its activity resulting in non-competitive inhibition of the enzyme. In this experiment we will be testing horseradish peroxidase an enzyme responsible for catalyzing the oxidation of various organic substrates with hydrogen peroxide and its response to temperature, $\mathrm{pH}$, and L-cysteine. You should compare the structure of the substrate $\mathrm{H}_{2} \mathrm{O}_{2}$ and L-cysteine and consider the fact that L-cysteine can be oxidized to L-cystine or absorb $\mathrm{O}_{2}$ to form cysteine sulfinic acid (Fig. 1).

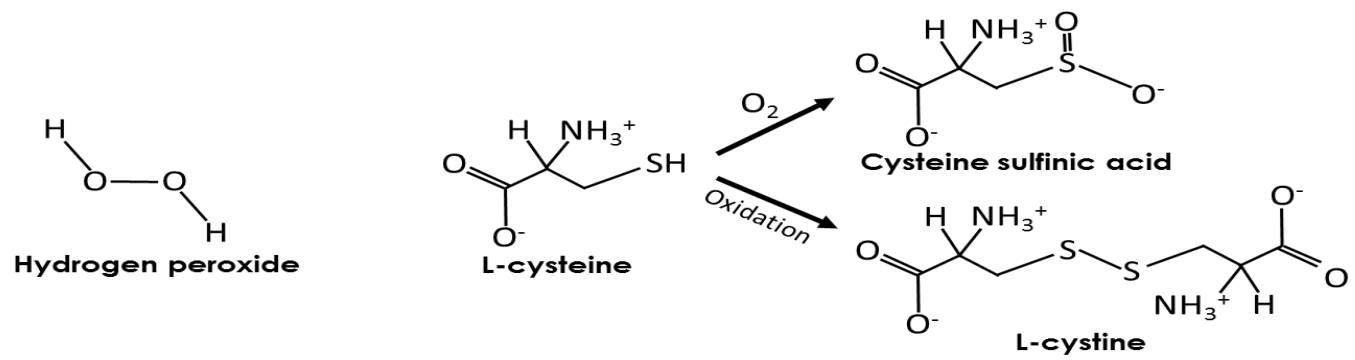

Figure 1. Comparison of structure between hydrogen peroxide and L-cysteine and the effect of $\mathrm{O}_{2}$ and oxidation on Lcysteine to produce cysteine sulfinic acid or L-cystine 


\section{Methods and Data Collection}

\section{Part A: Detection and Quantification of Peroxidase Activity by Oxidation of Guaiacol}

The peroxidase reaction can be monitored by using the compound guaiacol (2-methyoxyphenol) which can be oxidized to produce a brown product (tetraguaiacol) that can be detected and quantified by a spectrophotometer at $470 \mathrm{~nm}$ wavelength:

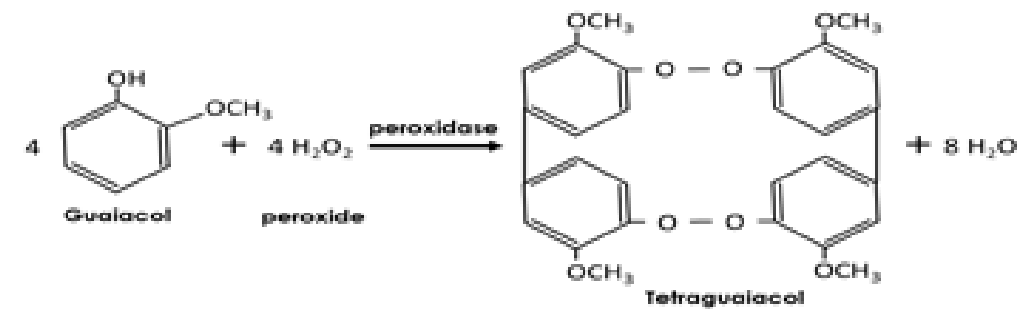

A standard reaction (Purdue University Instrument Van Project) will contain:

\begin{tabular}{|c|c|}
\hline $10 \mathrm{mM} \mathrm{H}_{2} \mathrm{O}_{2}$ substrate & $2 \mathrm{~mL}$ \\
\hline $25 \mathrm{mM}$ guaiacol indicator & $1 \mathrm{~mL}$ \\
\hline $0.1 \mathrm{M} \mathrm{NaPO}_{4}$ buffer $\mathrm{pH} 5$ & $2 \mathrm{~mL}$ \\
\hline Peroxidase $0.02 \mu \mathrm{g} / \mu \mathrm{L}$ & $10 \mu \mathrm{L}$ \\
\hline
\end{tabular}

To simplify the set up for you the substrate and indicator guaiacol have been combined for you as $3 \mathrm{~mL}$ substrate tubes ( $2 \mathrm{~mL}, 10 \mathrm{mM} \mathrm{H} \mathrm{O}_{2}$ and $1 \mathrm{~mL}$ guaiacol). You will need:

- eight substrate test tubes

- $\quad$ six $0.1 \mathrm{M} \mathrm{NaPO}_{4}$ buffer $\mathrm{pH} 5$ test tubes

\section{Part B: Determination of Peroxidase Activity (Positive Control)}

1. Turn on the spectrophotometer and let it warm up. After self-calibration and start up set the wavelength to $470 \mathrm{~nm}$.

2. Set up a blank tube to zero the spectrophotometer. This will contain all the material except the peroxidase enzyme. Mix a $0.1 \mathrm{M} \mathrm{NaPO}_{4}$ buffer $\mathrm{pH} 5$ tube to a $3 \mathrm{~mL}$ substrate tube. Wipe the tube with a Kimwipe ${ }^{\circledR}$ and insert the blank into the spectrophotometer and press the zero absorbance $/ 100 \%$ transmittance. Keep this tube to re-blank the spectrophotometer at the beginning of each experimental run.

3. Set up the reaction tube by adding the $10 \mu \mathrm{L}$ of peroxidase enzyme to a $2 \mathrm{~mL} 0.1 \mathrm{M} \mathrm{NaPO}_{4} \mathrm{pH} 5$ buffer tube then transfer this to a $3 \mathrm{~mL}$ substrate tube and mix thoroughly. Once the tubes are combined the reaction will begin. Wipe the tube with a Kimwipe ${ }^{\circledR}$ and immediately insert the tube into the spectrophotometer and record the absorbance at one-minute intervals for a total of 10 minutes. Record the absorbance values in Table 1 (positive control) or directly onto an excel spreadsheet.

\section{Part C: Effect of Temperature on Peroxidase Activity}

1. Place two substrate tubes in a test tube rack at room temperature on your bench.

2. Obtain two $\mathrm{NaPO}_{4}$ buffer $\mathrm{pH} 5$ tubes and add $10 \mu \mathrm{L}$ of peroxidase enzyme to each tube. Incubate one tube at $4^{\circ} \mathrm{C}$ and the second at $65^{\circ} \mathrm{C}$ for 15 minutes.

3. Use the blank you produced to zero the spectrophotometer.

4. After incubation add the $2 \mathrm{~mL}$ of incubated enzyme + buffer to the substrate reaction tube (this will be time zero) and mix thoroughly. Wipe the tube with a Kimwipe ${ }^{\circledR}$ and immediately insert the tube into the spectrophotometer and record the absorbance at one-minute intervals for a total of 10 minutes. Record the absorbance values in Table $1\left(4^{\circ} \mathrm{C}\right.$ and $65^{\circ} \mathrm{C}$ ) or directly onto an excel spreadsheet.

5. Repeat with the second temperature sample. By staggering the start times (time zero and time 30 seconds) you should be able to measure both samples over the same time course.

\section{Part D: Effect of pH on Peroxidase Activity}

1. Place two substrate tubes in a test tube rack at room temperature on your bench.

2. Obtain one $\mathrm{NaPO}_{4}$ buffer $\mathrm{pH} 4$ tube and one $\mathrm{NaPO}_{4}$ buffer $\mathrm{pH} 7$ tube and add $10 \mu \mathrm{L}$ of peroxidase enzyme to each tube. Incubate the tubes at room temperature for 15 minutes. 
3. Use the blank you produced to zero the spectrophotometer.

4. After incubation add the $2 \mathrm{~mL}$ of incubated enzyme + buffer to the substrate reaction tube (this will be time zero) and mix thoroughly. Wipe the tube with a Kimwipe ${ }^{\circledR}$ and immediately insert the tube into the spectrophotometer and record the absorbance at one-minute intervals for a total of 10 minutes. Record the absorbance values in Table 1 (pH4 and $\mathrm{pH} 7$ ) or directly onto an excel spreadsheet.

5. Repeat with the second $\mathrm{pH}$ sample. By staggering the start times (time zero and time 30 seconds) you should be able to measure both samples over the same time course.

\section{Part E: Effect of L-cysteine on Peroxidase Activity}

1. Place two substrate tubes in a test tube rack at room temperature on your bench.

2. Obtain two $\mathrm{NaPO}_{4}$ buffer $\mathrm{pH} 5$ tubes and add $10 \mu \mathrm{L}$ of peroxidase enzyme to each tube. Add $5 \mu \mathrm{L} 0.05 \mathrm{M}$ of L-cysteine to one tube and $10 \mu \mathrm{L}$ of $0.05 \mathrm{M} \mathrm{L}$-cysteine to the second tube. Incubate the tubes at room temperature for 15 minutes.

3. Use the blank you produced to zero the spectrophotometer.

4. After incubation add the $2 \mathrm{~mL}$ of incubated enzyme + L-cysteine + buffer to the substrate reaction tube (this will be time zero) and mix thoroughly. Wipe the tube with a Kimwipe ${ }^{\circledR}$ and immediately insert the tube into the spectrophotometer and record the absorbance at one-minute intervals for a total of 10 minutes. Record the absorbance values in Table 1 (L-cysteine) or directly onto an excel spreadsheet.

5. Repeat with the second L-cysteine sample. By staggering the start times (time zero and time 30 seconds) you should be able to measure both samples over the same time course.

Table 1. Peroxidase Activity.

\begin{tabular}{|c|c|c|c|c|c|c|c|}
\hline $\begin{array}{c}\text { Time } \\
\text { (minutes) }\end{array}$ & $\begin{array}{c}\text { Positive } \\
\text { control } \\
\text { Absorbance } \\
\text { (at 470nm) }\end{array}$ & $\begin{array}{c}\text { Absorbance } \\
\text { (at } 470 \mathrm{~nm} \text { ) } \\
\text { at } 4^{\circ} \mathrm{C}\end{array}$ & $\begin{array}{c}\text { Absorbance } \\
\text { (at } 470 \mathrm{~nm} \text { ) } \\
\text { at } 65^{\circ} \mathrm{C}\end{array}$ & $\begin{array}{c}\text { Absorbance } \\
\text { (at 470nm) } \\
\text { at pH } 4\end{array}$ & $\begin{array}{c}\text { Absorbance } \\
\text { (at } 470 \mathrm{~nm}) \\
\text { at pH } 7\end{array}$ & $\begin{array}{c}\text { Absorbance } \\
\text { (at 470nm) } \\
\text { with } 5 \mu \mathrm{L} \\
\text { 0.05M L- } \\
\text { cysteine }\end{array}$ & $\begin{array}{c}\text { Absorbance } \\
\text { (at } 470 \mathrm{~nm}) \\
\text { with } 10 \mu \mathrm{L} \\
\text { 0.05M L- } \\
\text { cysteine }\end{array}$ \\
\hline 1 & & & & & & & \\
\hline 2 & & & & & & & \\
\hline 3 & & & & & & & \\
\hline 4 & & & & & & & \\
\hline 5 & & & & & & & \\
\hline 6 & & & & & & & \\
\hline 7 & & & & & & & \\
\hline 8 & & & & & & & \\
\hline 9 & & & & & & & \\
\hline 10 & & & & & & & \\
\hline
\end{tabular}

$\underline{\text { Data Analysis }}$

To analyze the data you are collecting today, you will need to calculate initial velocity $(\mathbf{v})_{0}$ of the enzyme. This initial rate of reaction can be expressed simply as a change in absorbance per unit of time: for tetraguaiacol formation this would be $\Delta \mathrm{A}_{470 \mathrm{~nm}} / \mathrm{min}$ which corresponds to the slope on your absorbance vs. time graph.

To obtain the slopes of your data using excel:

1. Select/highlight your data

2. Select insert and under charts insert a scatter plot

3. A graph should appear on your spreadsheet. Select a data set and using the right mouse button and add a linear trend line and make sure to select display equation on chart so that you will be able to see the slope value

4. Use this value for your calculations

5. For some of your graphs only a portion may have a positive slope. You can calculate a slope from this region by typing (in the textbox at the top of excel) "=slope (select y coordinates, select x coordinates)". The slope calculation will now appear in the selected cell(s)

It is more useful to express the rate in terms of the amount of tetraguaiacol formed per unit time. This can be calculated as nanomoles per minute $(\mathrm{nmol} / \mathrm{min})$ or micromoles per minute $(\mu \mathrm{mol} / \mathrm{min})$. The absorbance value at $470 \mathrm{~nm}$ can be converted to an actual concentration using the Beer-Lambert law: 


$$
C=\frac{A}{\varepsilon(I)}
$$

$\mathbf{C}$ is the concentration of the absorbing material (tetraguaiacol, in our case), $\mathbf{A}$ is the absorbance measured at $470 \mathrm{~nm}$, and $I$ is the length of the light path $(1.0 \mathrm{~cm}$ for our spectrophotometers). The extinction coefficient $(\varepsilon)$ for tetraguaiacol at $470 \mathrm{~nm}$ is $26.6 \mathrm{mM}^{-1} \mathrm{~cm}^{-1}$ (Sigma Guaiacol data sheet). Using this value and the Beer-Lambert equation, we can convert an absorbance reading into an actual amount of product formed. Assume your slope was $0.5 / \mathrm{min}$ :

$$
\text { Concentration }=\frac{0.5 / \mathrm{min}}{(26.6 / \mathrm{mM}) * 1 \mathrm{~cm}}=0.019 \mathrm{mM} / \mathrm{min}=19 \mu \mathrm{M} / \mathrm{min}
$$

The units, $\mu \mathrm{M}$, are micromoles per liter, so a concentration of $19 \mu \mathrm{M}$, will be 19 micromoles per liter, or 19 nanomoles $/ \mathrm{mL}$. The reaction occurred in a total volume of $5.01 \mathrm{~mL}$, so to determine the total amount of tetraguaiacol product formed by the enzyme in one minute in the reaction instead of a concentration:

$$
19 \mathrm{nmoles} / \mathrm{ml} / \mathrm{min} \times 5.01 \mathrm{ml}=95.19 \mathrm{nmoles} / \mathrm{min}
$$

In summary, you'll need to follow three steps to get from your graph of absorbance vs. time to the amount of product formed per minute:

1. Determine the slope of the straight portion of your curve (units are $\Delta \mathrm{A}_{470} / \mathrm{min}$ ).

2. Convert this slope from $\Delta \mathrm{A}_{470} / \mathrm{min}$ to $\mu \mathrm{M} / \mathrm{min}$ by using the Beer-Lambert equation.

3. Convert this concentration to the total amount of product formed in the cuvette by taking the total volume into account. Report your result in terms of $\mathrm{nmol} / \mathrm{min}$.

We can also determine the product formation rate as a function of the amount of enzyme protein present or specific activity. To calculate this, divide the rate of product formation $\mathrm{x}$ reaction volume divided by the amount of enzyme used in the reaction (enzyme concentration $\mathrm{x}$ volume used in the reaction):

$$
\begin{gathered}
\text { Specific activity }=\left(\frac{\text { Slope of } 0.5 / \mathrm{min}}{(26.6 / \mathrm{mM}) * 1 \mathrm{~cm}}\right) \times 5.01 \mathrm{ml} /(0.02 \mathrm{mg} / \mathrm{ml} \times 0.01 \mathrm{ml} \text { used in reaction }) \\
=471 \mathrm{nmoles} / \mathrm{min} / \mathrm{mg} \text { protein }
\end{gathered}
$$

\section{Discussion}

1. Submit your graph of enzyme activity for peroxidase as if it were part of a formal lab: make sure it is properly formatted with a descriptive title.

2. Complete and submit table of peroxidase specific activity as if it were part of a formal lab: make sure it is properly formatted with descriptive title.

3. Describe the profile of the graph produced from exposing the peroxidase to the different concentrations and volumes of Lcysteine. Propose a hypothesis as to why the graph appears the way it does (hint: consider L-cysteine's shape and the fact it can absorb $\mathrm{O} 2$ or be oxidized). What type of inhibition does L-cysteine have on peroxidase? Explain.

\section{Cited References}

Purdue University Instrument Van Project: Factors Affecting Enzyme Activity. Obtained from: https://www.chem.purdue.edu/teacher/table of contents/Spectronic\%20Educator/ENZYME.pdf

Sigma Guaiacol data sheet. Obtained from: https://www.sigmaaldrich.com/content/dam/sigmaaldrich/docs/Sigma/Product_Information_Sheet/2/g5502pis.pdf 
Table 2. Recording of slope $\left(\Delta \mathrm{A}_{470 \mathrm{~nm}} / \mathrm{min}\right)$, determination of nmoles of product formed in one minute and specific activity

\begin{tabular}{|c|c|c|c|c|c|}
\hline $\begin{array}{c}\text { Enzyme and buffer } \\
\text { tube }\end{array}$ & $\begin{array}{c}\text { Substrate } \\
\text { reaction } \\
\text { tube }\end{array}$ & $\begin{array}{l}\text { Incubation } \\
\text { conditions }\end{array}$ & $\begin{array}{c}\text { Slope } \\
\left(\Delta \mathbf{A}_{470 \mathrm{~nm} / \mathrm{min}}\right)\end{array}$ & $\begin{array}{l}\text { nmoles of product } \\
\text { formed/minute }\end{array}$ & $\begin{array}{c}\text { Specific activity } \\
\text { (nmoles/min/mg } \\
\text { protein) }\end{array}$ \\
\hline $\begin{array}{c}2 \mathrm{~mL} \mathrm{NaPO}_{4} \text { buffer } \\
\mathrm{pH} 5+10 \mu \mathrm{L} \\
\text { peroxidase }\end{array}$ & $\begin{array}{c}2 \mathrm{~mL} \mathrm{H}_{2} \mathrm{O}_{2}+ \\
1 \mathrm{~mL} \\
\text { guaiacol }\end{array}$ & $\begin{array}{l}\text { Positive } \\
\text { control }\end{array}$ & & & \\
\hline $\begin{array}{c}2 \mathrm{~mL} \mathrm{NaPO}_{4} \text { buffer } \\
\text { pH5 }+10 \mu \mathrm{L} \\
\text { peroxidase }\end{array}$ & $\begin{array}{c}2 \mathrm{~mL} \mathrm{H}_{2} \mathrm{O}_{2}+ \\
1 \mathrm{~mL} \\
\text { guaiacol } \\
\end{array}$ & $\begin{array}{l}4^{\circ} \mathrm{C} \text { for } 15 \\
\text { minutes }\end{array}$ & & & \\
\hline $\begin{array}{c}2 \mathrm{~mL} \mathrm{NaPO}_{4} \text { buffer } \\
\text { pH5 }+10 \mu \mathrm{L} \\
\text { peroxidase }\end{array}$ & $\begin{array}{c}2 \mathrm{~mL} \mathrm{H}_{2} \mathrm{O}_{2}+ \\
1 \mathrm{~mL} \\
\text { guaiacol } \\
\end{array}$ & $\begin{array}{c}65^{\circ} \mathrm{C} \text { for } 15 \\
\text { minutes }\end{array}$ & & & \\
\hline $\begin{array}{c}2 \mathrm{~mL} \mathrm{NaPO}_{4} \text { buffer } \\
\mathrm{pH} 4+10 \mu \mathrm{L} \\
\text { peroxidase }\end{array}$ & $\begin{array}{c}2 \mathrm{~mL} \mathrm{H}_{2} \mathrm{O}_{2}+ \\
1 \mathrm{~mL} \\
\text { guaiacol }\end{array}$ & $\begin{array}{l}22^{\circ} \mathrm{C} \text { for } 15 \\
\text { minutes }\end{array}$ & & & \\
\hline $\begin{array}{c}2 \mathrm{~mL} \mathrm{NaPO}_{4} \text { buffer } \\
\mathrm{pH} 7+10 \mu \mathrm{L} \\
\text { peroxidase }\end{array}$ & $\begin{array}{c}2 \mathrm{~mL} \mathrm{H}_{2} \mathrm{O}_{2}+ \\
1 \mathrm{~mL} \\
\text { guaiacol }\end{array}$ & $\begin{array}{c}22^{\circ} \mathrm{C} \text { for } 15 \\
\text { minutes }\end{array}$ & & & \\
\hline $\begin{array}{c}2 \mathrm{~mL} \mathrm{NaPO}_{4} \text { buffer } \\
\mathrm{pH} 5+10 \mu \mathrm{L} \\
\text { peroxidase }+5 \mu \mathrm{L} \\
0.05 \mathrm{M} \text { L-cysteine }\end{array}$ & $\begin{array}{c}2 \mathrm{~mL} \mathrm{H}_{2} \mathrm{O}_{2}+ \\
1 \mathrm{~mL} \\
\text { guaiacol }\end{array}$ & $\begin{array}{l}22^{\circ} \mathrm{C} \text { for } 15 \\
\text { minutes }\end{array}$ & & & \\
\hline $\begin{array}{c}2 \mathrm{~mL} \mathrm{NaPO}_{4} \text { buffer } \\
\mathrm{pH} 5+10 \mu \mathrm{L} \\
\text { peroxidase }+10 \mu \mathrm{L} \\
0.05 \mathrm{M} \text { L-cysteine }\end{array}$ & $\begin{array}{c}2 \mathrm{~mL} \mathrm{H}_{2} \mathrm{O}_{2}+ \\
1 \mathrm{~mL} \\
\text { guaiacol }\end{array}$ & $\begin{array}{c}22^{\circ} \mathrm{C} \text { for } 15 \\
\text { minutes }\end{array}$ & & & \\
\hline
\end{tabular}




\section{Materials}

\section{Equipment and Supplies:}

A computer with Microsoft Excel ${ }^{\circledR}$

Visible wavelength spectrophotometer (Thermospectronic Genesys 20)

$13 \mathrm{~mm}$ Test tubes and snap caps

Water bath(s)

Volumetric dispensers or pipettes

$20 \mu \mathrm{L}$ Micropipetters

Lab coats

Safety glasses

\section{Solutions:}

A $0.1 \mathrm{M} \mathrm{NaPO}_{4}$ buffer:

$1 \mathrm{M}$ stocks of mono (Na) and dibasic $\left(\mathrm{Na}_{2}\right): 13.8 \mathrm{~g}$

monobasic in $100 \mathrm{ml} \mathrm{H}_{2} \mathrm{O}, 14.2 \mathrm{~g}$ dibasic in $100 \mathrm{ml} \mathrm{H}_{2} \mathrm{O}$.

Make $0.1 \mathrm{M}$ stock at $\mathrm{pH} 5: 2.1 \mathrm{~mL} 1 \mathrm{M}$ dibasic $+97.9 \mathrm{~mL}$ monobasic to a final volume of $1 \mathrm{~L}$.

Make $0.1 \mathrm{M}$ stock at $\mathrm{pH} 4: 1 \mathrm{~mL} 1 \mathrm{M}$ dibasic $+99 \mathrm{~mL}$ monobasic to a final volume of $1 \mathrm{~L}$.

Make $0.1 \mathrm{M}$ stock at $\mathrm{pH} 7: 57.7 \mathrm{~mL} 1 \mathrm{M}$ dibasic $+42.3 \mathrm{~mL}$ monobasic to a final volume of $1 \mathrm{~L}$.

Horse radish peroxidase (Fisher/alfa aesar j60026): stock is: $0.0014 \mathrm{~g}(1.4 \mathrm{mg})$ in $70 \mathrm{ml} \mathrm{NaPO}_{4}$ buffer $\mathrm{pH} 5$, gives final concentration of $0.02 \mathrm{mg} / \mathrm{mL}$ or $0.02 \mu \mathrm{g} / \mu \mathrm{L}$, can be aliquoted and stored at $-20^{\circ} \mathrm{C}$. Use $10 \mu \mathrm{L}$ per reaction.

0.05M L-cysteine HCl Monohydrate (Fisher/USB 14035): $0.01 \mathrm{~g}$ of powdered L-cysteine dissolved in $1.138 \mathrm{~mL}$ of $\mathrm{H}_{2} \mathrm{O}$. Affect starts at $\sim 5 \mu \mathrm{L}$ of stock solution $(5 \mu \mathrm{L}=$ final concentration of $50 \mu \mathrm{M} \mathrm{L}$-cysteine in $5 \mathrm{~mL}$ reaction volume), $60 \mu \mathrm{L}$ will stop the reaction for the full $10 \mathrm{~min}$.

25mM guaiacol (Fisher/ Acros Organics 120192500): $0.28 \mathrm{~mL} 100 \%$ guaiacol $+100 \mathrm{~mL}$ isopropanol. $10 \mathrm{mM}$ $\mathrm{H}_{2} \mathrm{O}_{2}$ substrate (Fisher 7722-84-1): $0.074 \mathrm{ml} 30 \% \mathrm{H}_{2} \mathrm{O}_{2}+$ $100 \mathrm{~mL} \mathrm{H}_{2} \mathrm{O}$.

Required volumes of solutions for all experiments listed above:

\begin{tabular}{|l|c|}
\hline \multicolumn{1}{|c|}{ Reagent } & Per group \\
\hline $10 \mathrm{mM} \mathrm{H}_{2} \mathrm{O}_{2}$ & $16 \mathrm{~mL}$ \\
\hline Peroxidase $(0.02 \mu \mathrm{g} / \mu \mathrm{L})$ & $70 \mu \mathrm{L}$ \\
\hline L-cysteine & $15 \mu \mathrm{L}$ \\
\hline $25 \mathrm{mM} \mathrm{guaiacol}$ & $8 \mathrm{~mL}$ \\
\hline $0.1 \mathrm{M} \mathrm{NaPO}_{4} \mathrm{pH} 5$ & $12 \mathrm{~mL}$ \\
\hline $0.1 \mathrm{M} \mathrm{NaPO}_{4} \mathrm{pH} 4$ & $2 \mathrm{~mL}$ \\
\hline $0.1 \mathrm{M} \mathrm{NaPO}_{4} \mathrm{pH} 7$ & $2 \mathrm{~mL}$ \\
\hline
\end{tabular}

\section{Notes for the Instructor}

We have found it is better to set up $\mathrm{NaPO}_{4}$ buffer tubes $(2 \mathrm{~mL})$ and separate guaiacol and $\mathrm{H}_{2} \mathrm{O}_{2}(3 \mathrm{~mL})$ substrate tubes into pre aliquoted $13 \mathrm{~mm}$ clear test tubes. Students just add the peroxidase enzyme to the buffer tube and incubate for required time/condition then add to substrate tube $(3 \mathrm{~mL})$. By combining these tubes and vigorously mixing the solutions together $(5 \mathrm{~mL}$ final volume) they are ready for spectrophotometer reading/time course. The assays can be done individually or staggered if time is limited. The use of different colored snap caps for each group of tubes (buffer and substrate) eases identification, limits mistakes and also reduces the amount of guaiacol odor released. Guaiacol is very pungent with the aroma of burnt wood or coffee, ventilation during and after the lab is recommended. We have found that an excel spreadsheet file already set up to display the graph and calculate the slope from the predicted linear portion of the graph is useful for students to visualize the results and analyze the data (Fig. 2).

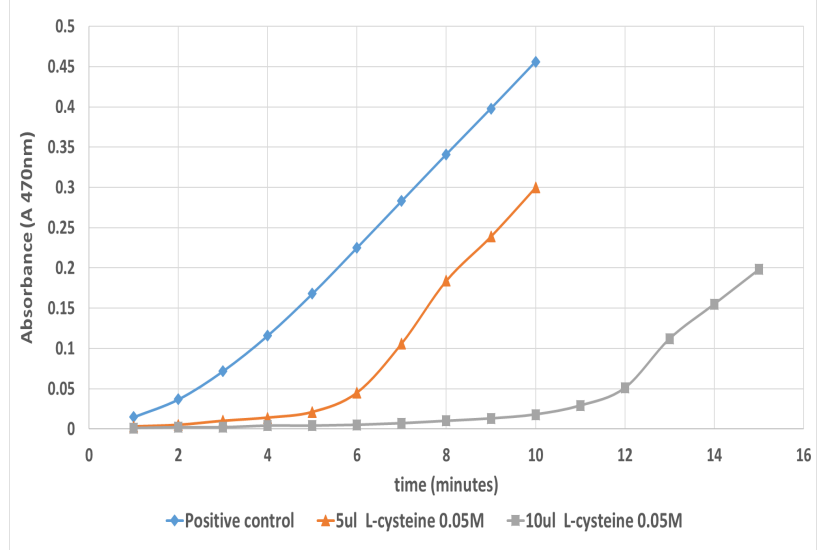

Figure 2. Typical peroxidase assay results with varying amounts of L-cysteine showing inhibition in time and concentration dependent manner.

\section{Cited References}

Baker CJ, Deahl K, Domek J, Orlandi EW. 2000. Scavenging of $\mathrm{H}_{2} \mathrm{O}_{2}$ and production of oxygen by horseradish peroxidase. Arch Biochem Biophys. 382(2):232-7.

Doerge DR, Divi RL, Churchwell MI. 1997. Identification of the colored guaiacol oxidation product produced by Peroxidases. Anal Biochem 250(1):10-17. 
Hiner AN, Hernández-Ruiz J, Williams GA, Arnao MB, García-Cánovas F, Acosta M. 2001. Catalase-like oxygen production by horseradish peroxidase must predominantly be an enzyme-catalyzed reaction. Arch Biochem Biophys. 392(2):295302.

Koduri, RS and Tien, M. 1995. Oxidation of Guaiacol by Lignin Peroxidase. J. Biol. Chem. 270: 22254 22258.

Maehly AC, and Chance B. 1954. Methods of Biochemical Analysis, New York: Interscience. 357-424p

Peroxidase inhibitors, Sigma bulletin. Obtained from: https://www.sigmaaldrich.com/lifescience/biochemicals/biochemicalproducts.html?TablePage $=15821520$

Purdue University Instrument Van Project: Factors Affecting Enzyme Activity. Obtained from: https://www.chem.purdue.edu/teacher/table_of_c ontents/Spectronic\%20Educator/ENZYME.pdf

Rojas-Reyes JO, Robles-Olvera V, Carvajal-Zarrabal O, Castro Matinez C, Waliszewski KN, and AguilarUscanga MG. 2014 Purification and characterization of peroxidase from avocado (Persea americana Mill, cv. Hass). J Sci Food Agric. 94(9):1844-53.
Sigma Guaiacol data sheet. Obtained from: https://www.sigmaaldrich.com/content/dam/sigm aaldrich/docs/Sigma/Product_Information_Sheet/ 2/g5502pis.pdf

Toledo JC Jr, Audi R, Ogusucu R, Monteiro G, Netto LE, Augusto O. 2011. Horseradish peroxidase compound I as a tool to investigate reactive protein-cysteine residues: from quantification to kinetics. Free Radic Biol Med. 50(9):1032-1038.

\section{Acknowledgments}

We would like to thank Dr. Carl Doige for information regarding this assay, Dr. Morgan Martin for reviewing the manuscript and procedure, the Okanagan College Salmon Arm Biology 121 lab students for trouble shooting this experiment and the 2019 ABLE participants for their feedback.

\section{About the Authors}

Michael Mitsch has been an Instructor at Okanagan College since 2004, where he teaches first year biology and anatomy and physiology classes and second year microbiology and genetics. Bryan White has been an Instructor at Okanagan College since 2014, where he teaches first year biology and anatomy and physiology classes. 


\section{Mission, Review Process \& Disclaimer}

The Association for Biology Laboratory Education (ABLE) was founded in 1979 to promote information exchange among university and college educators actively concerned with teaching biology in a laboratory setting. The focus of ABLE is to improve the undergraduate biology laboratory experience by promoting the development and dissemination of interesting, innovative, and reliable laboratory exercises. For more information about ABLE, please visit http://www.ableweb.org/.

Advances in biology laboratory education is the peer-reviewed publication of the conference of the Association for Biology Laboratory Education. Published articles and extended abstracts are evaluated and selected by a committee prior to presentation at the conference, peer-reviewed by participants at the conference, and edited by members of the ABLE Editorial Board. Published abstracts are evaluated and selected by a committee prior to presentation at the conference.

\section{Citing This Article}

Mitsch, M and White, B. 2020. A simple, quantitative peroxidase assay demonstrating enzyme inhibition with L-cysteine. Article 44 In: McMahon K, editor. Advances in biology laboratory educaiton. Volume 41. Publication of the 41st Conference of the Association for Biology Laboratory Education (ABLE). https://doi.org/10.37590/able.v41.art44

Compilation (C) 2020 by the Association for Biology Laboratory Education, ISBN 1-890444-17-0. All rights reserved. No part of this publication may be reproduced, stored in a retrieval system, or transmitted, in any form or by any means, electronic, mechanical, photocopying, recording, or otherwise, without the prior written permission of the copyright owner.

ABLE strongly encourages individuals to use the exercises in this volume in their teaching program. If this exercise is used solely at one's own institution with no intent for profit, it is excluded from the preceding copyright restriction, unless otherwise noted on the copyright notice of the individual chapter in this volume. Proper credit to this publication must be included in your laboratory outline for each use; a sample citation is given above. 